stand up to the strain of the racecourse as well as they do in their home island". Pressure of research in other directions is given as the reason for deferment of intensive study of the role of minor elements; but it seems fair to ask why the question of nutritional quality should be taken so fatalistically. The salary of a chemist or two would surely not be too much to add to an ordinary budget of chemical or veterinary investigation, and in conjunction with a rational policy of land use and nutrition would probably yield a high dividend.

The bulletin contains a large number of suggestive facts. Fiji has no native grass, the so-called 'native' grasses being importations which have run wild. In view of the decline of the natural indigo industry, it is interesting to learn that the cultivation of a trailing species of indigo for fodder and for purposes of soil protection is actually on the increase. What is a pest in one part of the world may be a useful grass in other parts of the world-or, as in Hawaii, in another part of one island.

HugH NrCoL.

\section{ECOLOGICAL PRINCIPLES AND FORESTRY}

$\mathrm{O}$ July 2, 1943, members of the forestry associations of Great Britain met at the invitation of the British Ecological Society to discuss problems arising from a paper by Sir Roy Robinson in Forestry, the journal of the Society of Foresters of Great Britain (see Nature, 152, 196 ; 1943). A fuller account of the meeting is now available (Forestry, $17 ; 1943$ ).

Prof. A. G. Tansley, in opening the meeting, said he welcomed the desire for a closer contact between ecology and forestry. He thinks foresters would, through ecology, find much to help them to a scientific rationale of their practical operations. Prof. Tansley stresses that scientific ecology is a very young subject of research, almost entirely a product of the present century and only developed energetically since the War of 1914-18. It is in this newness of the subject that may lie the danger for the young forester. As is said, it has only been really developed since the War of $3914-18$, and it is in this period that the word 'ecology' has come trippingly from the lips and pens of the young trained forester, the word being often made to serve as explanation for forestry processes as yet but dimly understood or assimilated by the junior. Prof. Tansley says: "I know very little of practical forestry, and I have often wished when I was teaching forestry students their elementary botany, and always from the general point of view of ecology, that I had had a practical training both in forestry and agriculture, just as I wished I had had a practical training in medicine when I was teaching biology to medical students. For just as scientific medicine is really a branch of applied biology, so forestry and agriculture may be regarded as branches of applied ecology."

To increase our knowledge of the ecology of woodlands, Prof. Tansley suggests a "continuous opportunity for access to and study of planting experiments together with the power of suggesting different variations and forms of control which are likely to lead to increased insight into the factors at work"-in fact, research work, which all foresters would welcome. It is, however, at present, a long step from this interesting and valuable work to the ordinary practical operations of the forester based on the growth of crops to produce marketable timber. Sir Roy Robinson's explanation that in afforestation work some species are pioneers and others are successors is obviously correct. But practical research is required to show how to shorten the experimental period in new afforestation work, if such a step is economically or ecologically possible from the financial point of view.

The experienced practical forester feels that a distinction should be sharply drawn between the true ecological research point of view and its work, and the practical sylvicultural activities of the executive forester who has to acquire a working knowledge of his soils in order to undertake his duties. In other words, the danger nowadays for the younger generations of foresters is that they may be led into sylvicultural inaction pending the outcome of the ecologists' experiments, giving the latter "the power to suggest different variations and forms of control" of the sylvicultural operations of the forester. The highly efficient sylvicultural management gradually brought into being in European Continental forestry departments was not attained by such means, though such research work will always prove of value to the sylviculturist when it has been brought to the point where its practical applications will obviously lead to better results.

\section{BIOLOGICAL STUDIES IN SOUTH AFRICA}

$T$

THE South African Journal of Medical Sciences, published quarterly by the University of Witwatersrand and the South African Institute for Medical Research, is devoted to original work in any of the sciences represented in the medical curriculum. C. de V. Bevan contributes to the February 1944 issue $(9$, No. 1$)$ an interesting article on the cultivation of the South African Rickettsiæ in developing chicks and the preparation of vaccines from the mem. branes of these. Dilute egg vaccines do not, he concludes, protect guinea pigs against epidemic infection, although they protect wholly against tick-borne infection and partially against endemic infection. Concentrated vaccines must be used in order to obtain complete protection against epidemic typhus produced by inoculation of guinea pigs with egg-passaged strains. A modified Machiavello technique for staining Rickettsiæ is described. The author finds that clearer staining is obtained if the smears are cleared in benzene. Bacteria and Rickettsiæ ground in a mortar with alundum are disintegrated. The development of the chick-embryo method will provide, the author thinks, smaller quantities of a far more potent vaccine than any that has yet been produced. The advantages of the egg-vaccine over the mammalian vaccines are discussed.

In the same issue, Margaret L. Creed discusses the nutritional value of a poor South African diet and of certain dietary supplements, and N. Sapeika reports on the digitalis action of a glycoside from the liliacean species Urginea rubella. More than twenty-five species of Urginea have been recorded in South Africa; many of these probably contain a toxic glycoside and a few are known to be toxic to stock. The issue concludes with a paper by O. S. Heyns and S. S. Hersch on the birth-weight of urban Bantu and the incidence among them of syphilis, still-birth and premature labour. 
The Biological Supplement to this jourmal is published separately. The February 1944 issue includes a noteworthy article by C. J. van der Horst on further stages in the embryological development of Elephantulus, the affinities of which with the Insectivora and Lemuroidea relate this study to the embryology of the primates and of man.

Christine Gilbert records work on the development of the post-renal segment of the inferior vena cava in the same species. G. H. Roux gives a beautifully illustrated account of the cranial anatomy of the marine amphibian Microhyla Carolinensis. Protozoology is represented by a description, by A.J. Gibbs, of the life-history of the Adeleid coccidian Chagasella sp., found in the salivary glands of the plant-feeding Hemipteran Cenceus carnifex.

G. Lapage.

\section{FORTHCOMING EVENTS}

Thursday, December 28

ROYAL INSTrTuTron (at 21 Albemarle Street, London, W.1), at Daily Life", 1 : "The Spinning Earth" (Christmas Lectures).

\section{Saturday, December 30}

NUTrimion SOcIETY (at the London School of Hygiene and Tropical Medicine, Keppel Street, London, W.C.1), at 11 a.m. - Conference on "The Nutritional Role of the Micro-Flora in the Alimentary Tract". minster, London, S.W.1), at 2.30 p.m.-Discussion on "The Choice of Materials for 'Scientific Photography" (Papers by Dr. H. Baines and Mr. F. J. Tritton).

ROXAI. INSTITUTION (at 21 Albemarle Street, London, W.1), at Daily Life", 2 : "The Revolving Earth" (Christmas Lectures).

\section{APPOINTMENTS VACANT}

APPLICATIONS are invited ANALYTTCAL CHEMIST FOR THE METALLCRGY DIVISION of the Service, Central (T aboratory -The Ministry of Labour and Nationa Kingsway, London, W.C.2 (quoting Reference No. F.3304.A) (December 27 ).

DEMONSTRATOR or AsSISTANT LECTURER (temporary) in BOTANYThe Acting Registrar, The University, Leeds 2 (December 30).

SPEECH THERAPIST-The Director of Education, Education Offices, Woodlands Road, Middlesbrough (December 30 ).

TEAoHer mainly for MATHEMATICS and ENGINEERING ScIrance in the Junior Technical School and in Senior Day and Evening ClassesThe Principal, County Technical College, Gainsborough, Lincs. The Principal,

AssistanT REgrsTrar-The Secretary, Bedford College for Women, ASSISTANT REGISTRAR-The Secretary, Bed
Regent's Park, London, N.W.1 (January 6).

RADIO DEVELOPMENT ENGINEERS for the laboratory of a large electrical engineering works in the N.W.-The Ministry of Labou Kingsway, London, W.C.2 (quoting Reference No. A.736.XA) (JanuKingsway,

ary 11). College of Science and Technology-The Academic Registrar, Univer sity of London, c/o Richmond College, Richmond, Surrey (February 26). PROFESSOR OF MATHEMATICS, and a PROFESSOR OF

Leorurtesh, Queen's University, Belfast (March 31). LEOTURTSHP IN MORAL PHILOSOPHY AND THE HISTORY OF PHILO-
sOPHY (including Greek Philosophy)-The Secretary, Queen's UniverSoPHY (including Greek

sity, Belfast (April 30),

LABORATORY STEWARD IN THE DHPARTMENT OF PATHOLOGY-The Secretary and Registrar, The University, Bristol.

\section{REPORTS and other PUBLICATIONS (not inciuded in the monthly. Booles Supplement)}

\section{Great Britain and Ireland}

City and Guilds of London Institute. Report of the Council to the Members of the Institute for the Year 1943. Pp. xlix. (London : City and Guilds of London Institute.)

Religious Instruction in Schools. Preliminary Statement prepared by a Committee of representatives of the Joint Conference of Anglicans and Free Churchmen, the Association of Education Comatitees and the National Union of Teachers. Pp. 8. (London: National Union
of Teachers.)
Britain and the World: an Outline of Reconstruction Problems. By the Hon. H. A. Wyndham. (Looking Forward Pamphlets, No. 1.) Pp. 60. (London and New York: Royal Institute of International Affairs.) 18. net. [311 Ministry of Aireraft Production. A College of Aeronautics : Report
of the Interdepartmental Commititee on the Establishment of a School of Aeronautical. Science. Pp. ii 98. (London: H.M. Stationery of Aeronautical Science. Pp. ii +98 . (London: H.M. Stationery
Office.) 28 . net. Science in Post-Primary Education, with reference to the Scientific Education in Schools of Pupils of 11-18, and its relation to their subsequent Training in Universities and Colleges. Interim Report of a vi +22 . (London: John Murray.) 18.3d. net. $\begin{array}{lr}\text { vi }+22 \text {. (London: John Murray.) 18. } 3 d \text {. net. } & {[911} \\ \text { An Annotated Bibliography of Medical Mycology, 1943. Edited }\end{array}$ An Annotated Bibliography of Medical Mycology, 1943. Edited
by Dr. S. P. Wiltshire, in collaboration with Dr. Charles Wilcocks and J. T. Duncan. Pp. 32. (Kew : Imperial Mycological Institute.) 58. net. $[911$ Lighting Reconstruction Pamphlet, No. 5: Public Lighting in the
City and Highway. Pp. 16. (London: Tluminating Engineering City and Highway. Pp. 16. (London: Tlluminating Engineering Society.) 18.
Imperial Bureau of Pastures and Forage Crops. Bulletin 31 : The Provision of Animal Fodder in Tropical and Subtropical Countries, Part 1. Pp. 84. 48. Bulletin 32: Advances in Grassland Husbandry and Fodder Production, First Symposium. Pp. 108. 48. (Aberystwyth: Imperial Bureau of Pastures and Forage Crops.) [911 Quality Control Chart Technique when Manufacturing to a Specifica tion: with Special Reference to Articles Machined to Dimensiona Tolerances. By Dr. B. P. Dudding and W. J. Jennett. Pp. iv +74.
(London: General Electric Co., Ltd.) 2s, 6 . (London: General Electric Co., Ltd.) 2s, 6d. A three-part Interim Report by the Reseach Board for the Correlation of Medical Science and Physical Education. Pp. $x x+119$. (London: Ling Physical Education Association.) $2 s$.
[911 Philosophical Transactions of the Royal Society of London. Series
B: Biological Sciences. No. 583. Vol. 231 : A Revision of Williamson. B : Biological Sciences. No. 583. Vol. 231 : A Revision of Williamson-
iella. By T. M. Harris. Pp. 313-328+plates 25-26. 48. 6d. No. 584, Vol. 231 : On Large-scale Sample Surveys. By P. C. Mahalanobis. Pp. 329-451. 198. (London: Cambridge University Press.) [911] Proceedings of a Conference on Problems in the Utilisation of Small Coals, held at the Institution of Civil Engineers, November 10th and 11th, 1943. Pp. 294. (London: British Coal Utilisation Research Association.)

[1411

Iron and Steel Institute. Special Report No. 30 : Ironmaking at By Appleby-Frodingham Works of the United Frodingham Ironworks, Scunthorpe, and of the Central Research Department, Stocksbridge (the United Steel Companies, Ltd.). Pp. vi $+280+16$ plates. (London : Iron and Steel Institute.) 168.

\section{Other Countries}

Imperial Council of Agricultural Research. Miscellaneous Bulpetin No. 58 : Canning of Tomatoes in Baluchistan. By Dr. G. S. Siddappa and A. M. Mustafa. Pp. $4+2$ plates. (Delhi : Manager of Publica-

tions.) 10 annas; 18 .
Memoirs of the San Diego Society of Natural History. Vol. 2: The Geology and Paleontology of the Marine Pliocene of San Diego, California. Part 1: Geology. By Leo George Hertlein and U. S, Grant, IV. Pp. $72+18$ plates. (San Diego: San Diego Society of Natural History.) 1.50 dollars.
Publications of the Dominion Observatory, 0ttawa Vol. 13 : Publications of the Dominion Observatory, Ottawa. Vol. 13 :
Bibliography of Seismology, No. 14: Items 5564-5673, July to Decem. Bibliography of Seismology, No. 14: Items 5564-5673, July to Decem. Printer.) 25 cents.

British Honduras. Report of the Forest Department for the Year ended 31st December 1943. Pp. 10. (Belize: Forest DepartImperial Council of Agricultural Research. Scientific Monograph No. 15: Dry Farming in India. By N. V. Kanitkar. Pp. $x+352$. (Delhi : Manager of Publications.) 13.12 rupees; $218.6 d$. The Organization of the New York Academy of Sciences; its Incor. poration, its Amended Charter, its Constitution and By-Laws, together with a Classifled List of its Members. Revised to August 1,1944 By Eunice Thomas Miner. Pp. 317-356. (New York: New York Academy

of Sciences.)
Cawthron Institute, Nelson, New Zealand. Annual Report, 1943-4. Pp. 35. (Nelson: Cawthron Institute.)

State of California Department of Natural Resources: Division of Fish and Game, Bureau of Marine Fisheries. Fish Bulletin No. 50 : By the Staff of the Bureau of Marine Fisheries. Pp. 68. (Sacramento: California State Printing Office.) [91]
[9. Brooklyn Botanic Garden Record. Vol, 33, No. 2 : C. Stuart-Gager Brooklyn Botanic Garden Record.
and the Brooklyn Botanic Garden. Pp. 69-178. (Brooklyn, N.Y. Brooklyn Institute of Arts and Sciences.) Bulletin of the American Museum of Natural History. Vol. 83, Art 5.: A Preliminary Study of the Thermal Requirements of Deser Reptiles. By Prof. Raymond Bridgman Cowles and Charles Mitchil Bogert. Pp. 261-296 + plates 19-29. (New York: American Museum
of Natural History.) of Academia Brasileira de Ciências. Symposium sôbre Raios Cósmicos, Rio de Janeiro, Agosto 4-8, 1941. Pp. $180+19$ plates. (Rio de Janeiro Rio de Janeiro, Agostemia Brasileira de Ciếncias.)
[911 University of Colorado Studies. Series B : Studies in the Humanities, Vol. 2, No. 2: Fitz-James O'Brien, a Literary Bohemian of the Eighteen-Fifties. By Prof. Francis Wolle. Pp. xi +309. (Boulder,
Colo.: University of Colorado.) 2 dollars.

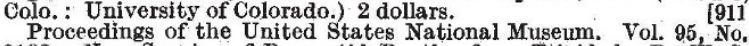
3183: New Species of Buprestid Beetles from Trinidad. By W. S Fisher. Pp. 397-410. (Washington, D.C.: Government Printing [1011 Smithsonian Institution: United States National Museum. Bulletin
185 : Checklist of the Coleopterous Insects of Mexico, Central America 185 : Checklist of the Coleopterous Insects of Mexico, Central America Blackwelder. Pp. iii $+189-342$. (Washington, D.C.: Government
Printing Office.) 30 cents. 